\title{
WAWASAN PENDIDIKAN (PENDIDIKAN DAN PENDIDIK)
}

\author{
Adib Fatoni \\ Fakultas Ushuluddin, Institute Agama Islam Negeri Kediri \\ Email: fatoni.adib@gmail.com
}

\begin{abstract}
Abstrak
Pendidikan pada hakikatnya adalah usaha sadar dan terencana untuk mewujudkan suasana belajar dan proses pembelajaran agar peserta didik secara aktif mengembangkan potensi dirinya untuk memiliki kekuatan spiritual keagamaan, pengendalian diri, kepribadian, kecerdasan, akhlak mulia, serta keterampilan yang diperlukan dirinya masyarakat, bangsa dan negara. Pendidikan nasional adalah pendidikan yang berdasarkan Pancasila dan UUD 1945 yang berakar pada nilai-nilai agama, kebudayaan nasional Indonesia, dan tanggap terhadap perubahan zaman. Fungsi dan tujuan pendidikan nasional tercantum dalam UU No. 20 tahun 2003 bab II pasal 3.

Keunggulan suatu bangsa tidak lagi bertumpu pada kekayaan alam, melainkan pada keunggulan sumber daya manusia, yaitu tenaga terdidik yang mampu menjawab tantangantantangan yang sangat cepat. Kenyataan ini sudah lebih dari cukup untuk mendorong pakar dan praktisi pendidikan melakukan kajian sistematik untuk membenahi atau memperbaiki sistem pendidikan nasional. Agar lulusan sekolah mampu beradaptasi secara dinamis dengan perubahan dan tantangan itu, pemerintah melontarkan berbagai kebijakan tentang pendidikan yang memberikan ruang yang luas bagi sekolah dan masyarakat untuk menentukan program dan rencana pengembangan sendiri sesuai dengan kebutuhan dan kondisi masing-masing.

Pendidikan menduduki posisi sentral dalam pembangunan karena sasarannya adalah peningkatan kualitas sumber daya manusia. Oleh karena itu, pendidikan juga merupakan alur tengah pembangunan dari seluruh sektor pembangunan. Pendidikan di Indonesia merupakan pendidikan yang diselenggarakan di Indonesia, baik terstruktur maupun tidak terstruktur. Pendidikan dapat diperoleh melalui pendidikan formal, pendidikan informal dan pendidikan nonformal. Ki Hajar Dewantara menyebutnya sebagai Tri Pusat Pendidikan yang terdiri dari pendidikan informal (keluarga), pendidikan formal (sekolah) dan pendidikan nonformal (masyarakat). ${ }^{1}$ Diperlukan kerja sama yang baik dan berkelanjutan antara ketiga pihak tersebut dalam mencapai tujuan pendidikan yang menghendaki tercapainya kehidupan anak-anak bangsa yang cerdas, berkarakter, kreatif, inovatif dan mempunyai konsep disiplin diri.

Keberhasilan suatu proses pendidikan tidak terlepas dari peran pendidik. Pendidik menduduki posisi penting sebagai sutradara yang merencanakan, mengatur dan

\footnotetext{
${ }^{1}$ Abdul Hafid Rahman,"Pemberian Hukuman sebagai Alat Pendidikan untuk menanamkan kedisiplinan...., 'Fakultas Tarbiyah dan Keguruan UIN Alauddin Makassar (Skripsi), hlm.2. from: http://repositori.uin-alauddin.ac.id/1022/ (diakses tanggal 14 Desember 2019)
} 
mengendalikan jalannya proses pendidikan. Semboyan Ki Hajar Dewantara menggambarkan betapa pentingnya posisi pendidikyaitu Ing Ngarso Sung Tulodo, Ing Madyo Mangun Karso, Tut Wuri Handayani. Semboyan ini memiliki arti bahwa setiap pendidik harus bisa menjadi contoh dan panutan bagi anak didiknya.

\section{A. LATAR BELAKANG}

Pendidikan telah ada sepanjang peradaban manusia dalam rangka melestarikan hidupnya karena sesederhananya peradaban suatu masyarakat, di dalamnya pasti terjadi atau berlangsung suatu proses pendidikan. Pendidikan merupakan bagian penting dari kehidupan yang sekaligus membedakan manusia dengan makhluk hidup lainnya. Hewan juga "belajar" tetapi lebih ditentukan oleh instingnya, sedangkan manusia belajar berarti merupakan rangkaian kegiatan menuju pendewasaan guna menuju kehidupan yang lebih berarti. Lebih jauh, pendidikan menurut Ngalim Purwanto adalah segala usaha orang dewasa dalam pergaulan dengan anak-anak untuk memimpin perkembangan jasmani dan rohaninya ke arah kedewasaan (2000:11). Anak-anak menerima pendidikan dari orang tuanya dan manakala anak-anak ini sudah dewasa dan berkeluarga mereka akan mendidik anak-anaknya, begitu juga di sekolah dan perguruan tinggi, para siswa dan mahasiswa diajar oleh guru dan dosen.

Pandangan klasik tentang pendidikan, pada umumnya dikatakan sebagai pranata yang dapat menjalankan tiga fungi sekaligus.Pertama,mempersiapkan generasi muda untuk memegang peranan-peranan tertentu pada masa mendatang. Kedua, mentransfer pengetahuan, sesuai dengan peranan yang diharapkan. Ketiga, mentransfer nilai-nilai dalam rangka memelihara keutuhan dan kesatuan masyarakat sebagai prasyarat bagi kelangsungan hidup masyarakat dan peradaban. Butir kedua dan ketiga di atas memberikan pengerian bahwa pandidikan bukan hanya transfer of knowledge tetapi juga transfer of value. Dengan demikian pendidikan dapat menjadi penolong bagi umat manusia lewat mendidik, mangajar, dan melatih siswa yang tergabung dalam sebuah proses pendidikan.

Segala proses pendidikan tersebut tidak pernah lepas dari figur seorang pendidik. Pendidik adalah tenaga kependidikan yang berkualifikasi sebagai guru, dosen, konselor, pamong belajar, tutor, instruktur, fasilitator, dan sebutan lain yang sesuai 
dengan kekhususannya, serta berpartisipasi dalam menyelenggarakan pendidikan. Mereka yang disebut pendidik adalah orang-orang yang dalam melaksanakan tugasnya akan berhadapan dan berinteraksi langsung dengan para peserta didiknya dalam suatu proses yang sistematis, terencana, dan bertujuan, baik dalam pendidikan, pembelajaran, maupun proses pelatihan.

Namun masalah yang terjadi saat ini adalah banyak sekali dijumpai pendidik yang tidak dapat membedakan antara mendidik, mengajar, dan melatih. Mereka mengira bahwa ketiga hal tersebut adalah sama. Selain itu pada masa sekarang, sasaran pengembangan pada diri siswa lebih dititikberatkan pada aspek kognitif dan rata-rata guru seringkali mengenyampingkan aspek afektif dan psikomotor. Hal ini terjadi karena telah ada dalam mindset sebagian masyarakat bahwa indikator keberhasilan pendidikan terletak hanya pada aspek kognitif. Selain itu, berhasil tidaknya sebuah proses pendidikan juga dipengaruhi oleh kualitas dari pendidik itu sendiri, apakah sudah memenuhi kompetensi sebagai seorang guru atau belum, memiliki kinerja dan tanggung jawab, serta akuntabilitas sebagai seorang pendidik atau belum.

Kondisi objektif inilah yang demikian inilah yang menarik perhatian penyusun untuk menganalisis dan mengkaji pengertian dan perbedaan mengajar, mendidik, dan melatih, sasaran pengembangan individu, indikator keberhasilan pendidikan yang sebenarnya, syarat-syarat pendidik, dan kinerja, kompetensi, tanggung jawab, serta akuntabilitas seorang pendidik sehingga pendidik memahami arti dari pendidikan dan kompetensi-kompetensi seorang pendidik.

\section{B. KAJIAN TEORI}

\section{Pengertian Mendidik, Mengajar, dan Melatih}

1) Mendidik

Menurut pengamatan di dunia, ada tiga macam pengertian pendidikan, yaitu:

a) Pendidikan dalam arti umum

Pendidikan dalam arti umum adalah pendidikan yang dilaksanakan oleh masyarakat pada umumnya dalam mengasuh anak-anak mereka. 
Semua lapisan masyarakat baik para orangtua, tokoh-tokoh masyarakat, para ketua organisasi kemasyarakatan, dan sebagainya bisa melaksanakan tugasnya mendidik anak-anak mereka. Walaupun hampir semuanya tidak mengenyam pembelajaran pendidikan sebagai ilmu, mereka dapat saja membina anak-anak atas dasar identifikasi terhadap cara-cara orangtua mendidik mereka dahulu dan pengalaman-pengalaman lainnya.

Atas dasar kenyataan tersebut, lalu munculah kritik terhadap pendidikan. Mereka tidak setuju dengan istilah pendidikan sebagai suatu ilmu sebab semua orang bisa mendidik. Namun kritik seperti itu tidak dapat diterima sepenuhnya sebab pendidikan pada masyarakat umum tidak selalu berhasil dengan baik. Untuk memberikan hasil yang baik, mereka perlu belajar tentang teori-teori pendidikan.

Untuk menolak kritikan tersebut, perlu dibuat definisi mendidik yang benar-benar mengarah kepada tugas ahli pendidikan. Definisi mendidik yang dimaksud adalah upaya menciptkan situasi yang kondusif sedemikian rupa sehingga peserta didik mau dan dapat belajar atas dorongan sendiri untuk mengembangkan semua potensi yang dimilikinya. Tekanan pada definisi ini adalah menciptakan situasi belajar yang dapat membangkitkan motivasi instrinsik peserta didik untuk belajar.

b) Teori Umum Pendidikan

Teori Umum Pendidikan sudah mengacu kepada pendidikan yang ilmiah karena cara-cara mendidik berdasarkan teori-teori atau konsepkonsep yang dikembangkan secara ilmiah. Aliran ini tidak mau menyebut dirinya sebagai ilmu pendidikan sebab penganutnya tidak membutuhkan pendidikan sebagai instrument atau alat mengembangkan peserta didik secara utuh. Hal ini disebabkan karena mereka menggunakan filsafat pragmatism yang berkembang di Amerika Serikat yang dipelopori oleh John Dewey. Filsafat ini meyakini apa yang benar adalah apa yag bermanfaat bagi manusia. Apa yang bermanfaat tahun ini belum tentu bermanfaat untuk tahun-tahun berikutnya. Oleh sebab itu, mereka tidak mau 
membuat tujuan pendidikan yang pasti. Karena tujuan pendidikan sangat mungkin untuk diubah-ubah, maka dipandang tidak ada gunanya membuat pendidikan sebagai instrument yang tetap . yang terpenting adalah proses pembelajaran yang tepat untuk mencapai sasaran tujuan pendidikan. Inilah yang mereka sebuat sebagai Teori Umum Pendidikan.

c) Ilmu Pendidikan

Ilmu pendidikan muncul pada tahun 1925 dan disahkan di Belanda oleh Langeveld. Ilmu pendidikan ini bersifat ilmiah, teratur, sistematis, dan merupakan suatu kebulatan.

Lebih jauh ilmu pendidikan ini seharusnya menyesuaikan diri dengan keadaan bangsa dan negara tempat dilaksanakannya. Di Indonesia misalnya, ilmu ini haruslah diatur isinya agar sesuai dengan flsafat negara pancasila, kebudayaan Indonesia, dan geografi Indonesia. Mengenai ruang lingkup pendidikan, pendidikan tidaklah hanya mencakup pengemabangan kepribadian saja sebagaiman tafsiran sejumlah orang. Mereka mengira mendidik hanyalah mengembangkan sikap sopan santun, menghargai orang lain, menghormati guru atau orangtua, dan lain sebagainya. Cakupan mendidik yang sebenarnya jauh lebh banyak dari hal-hal tersebut, antara lain membuat anak gemar membaca, gemar belajar, ingin banyak tahu, tidak mudah puas akan hasil kerjanya, tidak mudah putus asa, terampil mengerjakan sesuatu, dan perilaku-perilaku positif lainnya.

\section{2) Mengajar}

Kata mengajar berasal dari kata "ajar" yang artinya memberi pelajaran dari pendidik kepada peserta didik. Hal ini berbeda dengan pengertian mendidik yang menekankan pada upaya mengembangkan potensi-potensi yang ada dalam diri peserta didik itu sendiri. Dengan demikian, mengajar dapat disebut sebagai upaya mentranformasikan pengetahuan, ilmu, teknologi, dan seni. Keempat kelompok pengetahuan tersebut seolah-olah dipindahkan dari pendidik atau dari sumber-sumber lain kepada peserta didik. Proses pemindahan itulah yang disebut sebagai mengajar. 
Dalam perkembangannya, kata "mengajar" berubah menjadi belajar mengajar. Perubahan ini disebabkan oleh terjadinya pembaharuan konsep proses belajar para peserta didik. Kalau semula proses belajar itu sebagian besar diperankan oleh pendidik, maka yang digunakan adalah kata "mengajar". Dalam perkembangan berikutnya, peranan bukan lagi mengacu pada pendidik, melainkan ada pada peserta didik. Itulah sebabnya istilah mengajar berganti menjadi belajar mengajar.

Proses mengajar pada perkembnagan terakhir tidak sama lagi penekanannya antara peserta didik dengan pendidik, melainkan ada pada peserta didik. Peserta didiklah yang aktif belajar mengembangkan diri, kepribadian, bakat, pengetahuan, dan keterampilannya untuk menjadi manusia dewasa yang dapat mandiri dan menjadi warga negara yang baik. Sementara itu pendidik hanya bertindak sebagai fasilitator, yaitu merencanakan dan menyiapkan serta mengatur segala sesuatu untuk keperluan belajar peserta didik. Inilah yang mmebuat istilah belajar-mengajar berubah lagi pada perkembangan ketiga ini menjadi pembelajaran.

3) Melatih

Disamping dididik dan belajar, peserta didik juga perlu dilatih. Jika dalam proses pendidikan dan pembelajaran peserta didik hamper seluruhnya menggunakan rohaninya, maka dalam proses berlatih, peserta didik sebagian besar menggunakan jasmani dan sebagian kecil rohani. Pemakaian rohani tidak bisa ditinggalkan mengingat dalam proses latihan jasmani selalu dikendalikan dan dikontrol oleh rohani.

Latihan yang paling sedikit menggunakan jasmani adalah proses pembelajaran dalam pendidikan formal. Proses belajar pada pendidika formal ini hamper semuanya melaksanakan latihan pada peserta didiknya, disamping melakukan pendidikan dan pengajaran. Namun proporsi latihan pada umumnya lebih kecil dibandingkan dengan mengajar dan mendidik. Besar kecilnya waktu yang dipakai berlatih bergantung pada sifat materi yang dipelajari.

4) Perbedaan antara Mendidik, Mengajar, dan Melatih 
Perbedaan antara mendidik, mengajar, dan melatih lebih jelasnya dapat dilihat dalam table 2.1 berikut:

\begin{tabular}{|c|c|c|c|}
\hline Aspek & Mendidik & Mengajar & Melatih \\
\hline Isi & Moral dan kepribadian & $\begin{array}{l}\text { Bahan ajar berupa } \\
\text { ilmu pengetahuan dan } \\
\text { teknologi }\end{array}$ & $\begin{array}{ll}\text { Ketrampilan atau } \\
\text { kecakapan hidup }\end{array}$ \\
\hline Proses & $\begin{array}{l}\text { Memberikan motivasi } \\
\text { untuk belajar dan } \\
\text { mengikuti ketentuan/ } \\
\text { tata tertib yang telah } \\
\text { menjadi kesepakatan } \\
\text { bersama }\end{array}$ & $\begin{array}{l}\text { Memberikan contoh } \\
\text { kepada siswa/ } \\
\text { mempraktikkan } \\
\text { ketrampilan tertentu/ } \\
\text { menerapkan konsep } \\
\text { yang diberikan kepada } \\
\text { siswa menjadi } \\
\text { kecakapan yang dapat } \\
\text { digunakan sehari-hari }\end{array}$ & $\begin{array}{l}\text { Menjadi contoh } \\
\text { teladan dalam hal } \\
\text { moral dan kepribadian }\end{array}$ \\
\hline $\begin{array}{l}\text { Strategi } \\
\text { dan } \\
\text { Metode }\end{array}$ & $\begin{array}{l}\text { Keteladanan, } \\
\text { pembiasaan }\end{array}$ & Ekspositori, enkuiri & $\begin{array}{l}\text { Praktik kerja, } \\
\text { simulasi, magang }\end{array}$ \\
\hline
\end{tabular}

Mendidik, mengajar, dan melatih adalah unsur-unsur yang selalu ada dalam pendidikan formal setiap mempelajari sesuatu. Pendidikan terjadi untuk membangkitkan motivasi dan kegiatan peserta didik belajar. Sementara itu pembelajaran terwujud ketika peserta didik mempelajari sesuatu lewat materi dan alat belajar yang relevan. Sedangkan pelatihan dibutuhkan agar peserta didik terampil, cepat, dan tepat menyelesaikan tugas yang sudah ditetapkan. Dengan demikian, pelatihan dibutuhkan ketika peserta didik sudah paham akan hal yang dipelajari untuk membuat mereka menjadi mantap akan penguasaan materi itu. Jadi, pemakaian waktu untuk mendidik, mengajar, dan melatih haruslah proporsional.

\section{Sasaran Pengembangan Individu}

Sasaran pengembangan individu merupakan pengembangan seluruh potensi alamiah yang dimiliki setiap individu dan tidak terbatas pada lingkungan sekolah atau lembaga pendidikan. Pengembangan individu tidak hanya mencakup penguasaan materi pada mata pelajaran saja, namun mencakup kemampuan 
keterampilan yang dimiliki setiap peserta didik dan pengembangan perilakuperilaku yang lainnya. Tugas pendidikan yaitu mengembangkan semua kemampuan yang dimiliki peserta didik, agar setiap peserta didik dapat berkembang secara utuh dan lengkap dengan semua unsur yang ada. Sehingga mereka kelak ketika sudah berkembang akan menjadi individu-individu yang dapat hidup secara mandiri dan menjadi warga masyarakat yang baik.Berikut ini merupakan unsur-unsur individu:

1) Rohani

a. Pribadi

1) Perilaku beragama

2) Perasaan

3) Kemauan

4) Pikiran

b. Sosial

1) Kemasyarakatan

2) Cinta tanah air

2) Jasmani
a. Keterampilan
b. Kesehatan
c. Keindahan tubuh

Pada bagian berikut diuraikan secara singkat masing-masing unsur yang perlu dikembangkan. Pertama yaitu unsur rohani mencakup pribadi dan sosial, yang dimaksud unsur pribadi merupakan diri seseorang itu sendiri dan tidak sama antar satu sama lain. Sementara itu unsur pribadi mencakup perilaku beragama, perasaan, kemauan, dan pikiran. Perilaku beragama memegang peranan penting dalam kehidupan individu karena nilai-nilai yang terkandung dalam agama merupakan nilai mulia yang bermanfaat untuk kehidupan di masyarakat. Selanjutnya perasaan, dalam bermasyarakat sangat perlu memiliki perasaan yang baik agar dapat bergaul dan berteman secara baik maupun memiliki toleransi yang tinggi dengan orang lain. Tentang kemauan, berkaitan dengan tindakan untuk mempelajari sesuatu, 
mengejar sesuatu dan bekerja keras dalam menggapai cita-cita. Sedangkan pikiran merupakan alat individu untuk memecahkan masalah, mencari strategi, dan metode untuk menyelesaikan pekerjaan secara efektif dan efisien.

Pada bagian kedua ini mengenai pengembangan sosial, hal ini juga sama pentingnya dengan pengembangan pribadi yaitu mencakup kemasyarakatan dan cinta tanah air. Pengembangan unsur kemasyarakatan sangat berguna bagi individu bersangkutan dalam menjalani hidup bersama dengan saling menghormati, bekerja sama, dan mencapai kepentingan bersama baik dalam keluarga, masyarakat, maupun sebagai warga negara. Selanjutnya tentang cinta tanah air, pengembangan ini dilakukan untuk memperkuat pengembangan kemasyarakatan, khususnya kemasyarakatan dalam lingkup bangsa dan negara.

Dalam diri individu tidak dapat dipisahkan antara unsur rohani dan jasmani, keduanya saling terkait, saling menunjang dan saling mempengaruhi. Apabila jasmani sakit seringkali rohani jadi terganggu, begitu sebaliknya jika rohani sehat maka jasmani tidak akan mudah terkena penyakit. Pengembangan jasmani mencakup pengembangan keterampilan, kesehatan, dan keindahan tubuh. Pengembangan keterampilan sangat dibutuhkan karena pada dasarnya setiap kegiatan dan pekerjaan membutuhkan keterampilan dari setiap individu dan akan berbeda antara satu sama lain. Selanjutnya tentang pengembangan kesehatan, setiap orang wajib berpikir bagaimana cara agar dirinya tetap sehat dan terhindar dari penyakit serta penanganan secara dini apabila terkena penyakit. Hal itu dilakukan agar mereka tetap sehat dan dapat melaksanakan tugas hidupnya dengan baik. Unsur yang terakhir yaitu pengembangan keindahan tubuh erat kaitannya dengan kesehatan, ia merupakan aspek estetika. Pengembangan keindahan tubuh menjadi penting karena memiliki tubuh yang indah berarti individu tersebut secara tidak langsung sudah menjaga kesehatannya, hal itu misalnya dilakukan dengan cara olahraga. Memiliki tubuh yang indah pada jaman sekarang bukan hanya dilakukan pada individu remaja saja, namun individu yang lanjut usiapun juga ikut menjaga keindahan tubuhnya. 



\section{Indikator keberhasilan pendidikan}

Masyarakat umum dan pengembangan individu memiliki pandangan yang sama terhadap kriteria keberhailan pendidikan. Keberhailan pendidikan tersebut dilihat dari kriteria nilai rapor dan nilai tes yang baik. Hal seperti ini merupakan tidak benar jika ditinjau dari segi teori pendidikan. Kriteria keberhasilan pendidikan itu seharunya mencakup semua hal yang bertalian dengan kehidupan manusia.

Kriteria keberhasilan pendidkan dapat ditinjau dari kualitas, produktivitas dan kelulusan lembaga pendidikan. Ditinjau dari segi kualitas meliputi kontks latar belakang sekolah, calon peserta didik, proses pembelajaran, kelulusan, dan kemampuan lulus bekerja, mandiri, dan menjadi warga Negara yang baik setelah lulus sekolah. Bila ditinjau dari produktivitas meliputi kelulusan, pembelajaran, penelitian, karya nyata, jasa dan sebagainya. Sedangkan kita bicara kedua kriteria tersebut akan bermuara pada kelulusan.

Namun kalau kriteria keberhasilan pendidikan dititikberatkan pada kelulusan, maka perlu diulang kembali peran pendidikan, pengajaran, dan pelatihan. Dari ketiga peran tersebut tampak bahwa pendidikan memegang peran utama, ini dikarenakan pengajaran hanyya memberikan hal-hal baru, pelatihan merupakan memperkuat dan mempertebal pengetahuan peserta didik, sedangkan pendikan untuk mengunggah hati, kemauan, tekad dari peserta didik. Dengan kata lain jika pendidikan berhasil maka pengajaran dan pelatihanpun berhasil.

Dari uraian di atas dapat disarikan kriteria keberhailan pendidikan khusus tentang aspek kelulusan adalah sebagai berikut:

1) Punya sikap suka belajar

2) Tahu cara belajar

3) Punya rasa percaya diri

4) Encintai prestasi tinggi

5) Meiliki etos kerja baik

6) Kreatif dan produktif 


\section{Syarat-syarat pendidik: pribadi, pendagogik, akademik, dan social}

Pada zaman sekarang untuk pembicaraan tentang syarat-syarat pendidik, kembali kepada calon pendidik itu sendiri, ini dikarenakan penghasilan para pendidik relatif paling rendah dibandingkan dengan penghasilan petuas instansiinstansi lain. Akibatnya hampir semua orang mengindari untuk menjadi tenaga pendidik. Mereka mau menjadi pendidik kalau dalam keadaan terpaksa. Dampak dari kondisi ini akan suit mendapatkan calon-calon pendidik yang berkualitas. Hal ini sudah disadari oleh pemerintah, sehingga pemerintah meinaikan anggaran pendidikan $20 \%$ dan mengadakan sertifikasi kepada para pendidik.

Namun dengan hal diatas tidak semuanya akan berhasil, ini disebabkan para pendidik sebagian besar berasal dari calon-calon pendidik yang berpotensi tidak begitu tinggi. Tetapi upaya pemerintah tersbut akan berdampak dengan seiring waktu, karena upaya tersebut akan menyisihkan pendidik-pendidik yang handal dimasa mendatang. Pembaharuan dalam penanganan dunia kerja terebut juga akan terjadi pada personalia lain dalam lingkup dunia pendidikan. Personalia ini disebut dengan satu istilah yaitu tenaga kependidikan. Tenaga kependidikan ini terdiri dari (UUSPN, 2003:27).

1) Pengelola

2) Peneliti dan pengembang kurikulum

3) Pengawas dan supervisor

4) Teksi pembelajaran (laboran, pustakawan, pusat sumber belajar)

5) Tenaga tatausaha

Tiga dari lima macam tenaga kependidikan mempunyai kewajiban yang bersentuhan lansung dengan kewajiban pendidik, yaitu pengelola atau kepala sekolah, pengembang kurikulum dan supervisor.

Dalam Peraturan Pemerintahan RI Nomor 19 (2005: 24) dituliskan kompetensi pendidik mencakup kompetensi pedagogik, kepribadian, professional, dan sosial.

1) Pribadi pendidik 
Pribadi syarat utama bagi pendidik mengingat peranan pribadi itu sangat besar mempengaruhi perkembangan peserta didik. Dalam hal ini peserta didik secara sadar atau tidak, akan meniru kebiasaan pendidik-pendidiknya yang tiap kali dia temui pada proses pembelajaran. Pengaruh pribadi terhadap peserta didik disebut keteladanan (Daresh, 2000: 283). Ketauladanan ini cukup efektif mempengaruhi prilaku peserta didik. Kepribadian pendidik di Indonesia seharusnya menjadi penyaring pribadipribadi baru yang muncul lewat globalisasi.

2) Pedagogik

Pendagogik adalah ilmu pendidikan, ini berarti adanya cara-cara mendidik peserta didik agar menjadi berkembang sesuai dengan cita-cita tujuan pendidikan Indonesia. Perbedaan mendidik dan mengajar yaitu mengajar adalah mentrasfer ilmu kepada peserta didiik, sehingga peserta didik dari tahu menjadi tahu. Adapun mendidik merupakan mengembangkan semua potensi peserta didik menjadi realita. Jadi pendidik harus dapat menggerakkan hati dan jiwa peserta didik untuk aktif mngembangkan dirinya.

Berikut hal-hal yang perlu dilakukan pendidik:

a) Sebagai fasilator pendidik

b) Menjadi pembimbing para siswa

c) Menjadi model prilaku yang akan ditiru

d) Sebagai guru konsoler

e) Menjadi mitra peserta didik

f) Melaksanakan disiplin permisif

g) Memberi kebebasan dalam mengaktualisasi diri

h) Melayani pengembangan bakat

i) Memberi kesempatan kreatif

j) Berdialog agar peserta didik berfikir kritis

k) Membina prilaku sehari-hari agar positif

1) Mengembangkan karakter berbangsa pada setiap anak 
3) Akademik

Kompetensi akademik mencakup tiga hal yaitu:

a) Metode pembelajaran

b) Psikologi belajar anak

c) Penguasaan materi pelajaran

Metode pembelajaran merupakan suatu cara untuk menyampaikan ilmu kepada peserta didik. Ini penting sebab setiap materi itu memiliki metode-metode tertentu untuk dapat diinternalisasi oleh peserta didik. Keberhasilan dalam menentukan metode pembelajaran akan menentukan keberhasilan proses belajar. Proses belajar ini penting, karena dari proses belajar menentukan baik buruknya hasil belajar.

Psikologis belajar anak harus menjadi perhatian dari pendidik, karena dalam proses mendidik pskologi anak sangat berperan banyak, diantaranya minat, bakat, hobi, kemampuan umum, watak dan kepribadian. Ini semua dapat dimanfaatkan oleh pendidik untuk peserta didik rajin dan tekun mengembangkan dirinya. Mengengenai penguasai materi pelajaran, secara logis harus terjadi pada setiap pendidik tentang materi pelajaran yang akan mereka ajarkan. 
d) Sosial

Tenaga pendidik harus memiliki sifat sosial dan berhubungan dengan masyarakat dan lembaga-lembaga pendukung pendidikan personalia lembaga pendidik lainnya, dan dengan peserta didik. Menurut Terry (2000: 87) menyebutkan bahwa integritas sosial ini meupakan salah satu kualiikasi pendidik, yang mecakup objektivitas, kemampuan berkomunikasi, ketegasan, kesadaran akan harapan peserta didik serta merealisasi harapan itu. Selain dengan lembaga pendukung pendidikan, para pendidik harus memiliki sifat sosial dengan masyarakat. Sifat sosial ini bermanfaat masyarakat paham akan upaya sekolah membantu mengembangkan putra-putri mereka.

\section{Kinerja, Kompetensi, Tanggungjawab, dan Akuntabilitas Pendidik}

Sebagai calon pendidik kita perlu memahami perbedaan antara profesi, kinerja, dan kopmpetensi. Selain itu juga harus dapat membedakan antara tanggungjawab dengan akuntabilitas. Hubungan-hubungn tersebut akan diuraikan pada bagian berikut:

1) Kinerja dan Kompetensi

Secara ideal semua ciri profesi seharusnya terkuasai dan dapat diaplikasikan dengan baik oleh setiap pendidik. Ciri-ciri profesi yang bertalian dengan tugas pendidik dalam mendidik dan proses pembelajaran itulah yang disebut kompetensi. Jadi, Kompetensi pendidik adalah kemampuan ideal mereka dalam proses pembelajaran.

Kompetensi yang terealisasi atau yang dapat diamati itulah yang disebut kinerja pendidik. Jadi, kinerja adalah kemampuan atau perilaku yang dapat diamati dalam praktek sehari-hari ketika melaksanakan tugas mendidik, mengajar, dan melatih.

Untuk memajukan kinerja pendidik bahwa faktor-faktor yang berpengaruh positif terhadap semangat kerja pendidik adalah pendidikan, gaji, kepemimpinan ketua lembaga dan kondisi lembaga pendidikan. 
2) Tanggungjawab dan Akuntabilitas

Tanggungjawab adalah upaya menyelesaikan tugas-tugas yang dibebankan oleh atasan terhadap bawahan atau oleh suatu tim kepada para pendidik. Tugastugas tersebut berupa tugas pokok dan tugas tambahan. Tugas-tugas itu termasuk sifat penyelesaiannya yang mencangkup kuantitas, waktu, dan kualitas tersebut direncakan oleh tim atau oleh pengelola lembaga pendidikan.

Akuntabilitas lebih tinggi daripada tanggungjawab sebab untuk mencapai kualitas akuntabel membutuhkan kemampuan yang tinggi, dedikasi dan motivasi yang lebih besar serta teliti dan tekun dalam menyelesaikan pekerjaan. Tanpa kualitas kemampuan dan disiplin yang prima ini sulit untuk mencapai akuntabilitas.

Pada akuntabilitas terdapat teori akuntabilitas guna terlaksananya akuntabilitas tersebut yaitu adanya kesepakatan. Dalam kesepakatan bersama, sesudah melalui diskusi yang memadai, maka ditentukanlah apa yang akan dikerjakan, berapa waktu yang dibutuhkan menyelesaikan pekerjaan itu, dan seperti apa proses pengerjaan itu serta kualitas hasil yang ditargetkan. Kesepakatan tersebut kemudian dijadikan standar atau kriteria yang dipegang bersama dalam melaksanakan pekerjaan itu. Kemudian orang-orang yang berkepentingan yang merasakan kinerja dari kesepakatan tersebut yang telah memenuhi standar. Kalau sebagian terbesar merasa puas pada proses dan hasil kerja itu maka terjadilah akuntabilitas.

\section{Simpulan}

1. Perbedaan antara pendidikan, pengajaran, dan pelatihan adalah pendidikan dilakukan untuk membangkitkan motivasi dan kegiatan peserta didik belajar. Sementara itu pembelajaran terwujud ketika peserta didik mempelajari sesuatu lewat materi dan alat belajar yang relevan. Sedangkan pelatihan dibutuhkan agar peserta didik terampil, cepat, dan tepat menyelesaikan tugas yang sudah ditetapkan

2. Sasaran pengembangan individu meliputi aspek rohani dan jasmani. Aspek rohani meliputi perilaku beragama, perasaan, kemauan, pikiran, kemasyarakatan, dan cinta 
tanah air. Sedangkan aspek jasmani meliputi keterampilan, kesehatan, dan keindahan tubuh (kesehatan)

3. Indikator keberhasilan pendidikan dapat ditinjau dari segi produktivitas lembaga pendidikan, kualitas lembaga, dan lulusan lembaga yang menguasai aspek kognitif dan afektif.

4. Kompetensi yang harus dimiliki oleh seorang pendidik adalah kompetensi pribadi, pedagogik, sosial, dan profesional

5. Knerja pada umumnya lebih terbatas jangkauannya daripada kompetensi, begitu juga mutu kinerja lebih rendah daripada kompetensi. Sedangkan akuntabilitas lebih tinggi daripada tanggung jawab sebab untuk mencapai kualitas akuntabel membutuhkan kemampuan yang tinggi, dedikasi, dan motivasi yang lebih besar serta teliti dan tekun dalam menyelesaikan suatu pekerjaan.

\section{Saran}

1. Komitmen guru dan dedikasi yang tinggi terhadap mutu pembelajaran dan dunia pendidikan sangat diperlukan sehingga guru merupakan kunci kesuksesan belajar siswa dan kualitas pendidikan.

2. Guru hendaknya memiliki kesadaran tinggi untuk memiliki kualifikasi sebagai pendidik yang memiliki kompetensi social, pribadi, pedagogik, dan professional yang mampu mengembangkan potensi dan karakter peserta didik.

3. Indikator keberhasilan pendidikan jangan dilihat hanya dari aspek kognitif saja, melainkan juga afektifnya.

\section{DAFTAR PUSTAKA}

Basri, Hasan. 2013. Landasan Pendidikan. Bandung : Pustaka Setia

Pidarta, Made. 2007. Landasan Kependidikan Stimulus Ilmu Pendidikan Bercorak Indonesia. Jakarta : Rineka Cipta

Pidarta, Made. 2013. Wawasan Pendidikan. Surabaya : University Press

Purwanto. Ngalim. 2000. Ilmu Pendidikan Teoritis dan Praktis. Bandung : Remaja Rosdakarya

Https://agusprayugo.wordpress.com/tag/perbedaan-mengajar-dan-mendidik/ [Diakses pada tanggal 17 September 2019] 